\title{
Transvaginal Aspiration of Ectopic Gestational Sac: A Novel Treatment Option in Tubal Ectopic Pregnancies
}

\author{
${ }^{1}$ Vineet V Mishra, ${ }^{2}$ Sumesh Choudhary, ${ }^{3}$ Urmila Sharma, ${ }^{4}$ Ritu Agarwal
}

\begin{abstract}
Objective: To present five cases of unruptured tubal ectopic pregnancies treated with ultrasound-guided aspiration with local potassium chloride $(\mathrm{KCl})$ or systemic methotrexate (MTX) administration.
\end{abstract}

Design: Case series.

Setting: A hospital-based prospective study.

Patients: Five women with unruptured tubal ectopic pregnancy.

Interventions: Transvaginal ultrasound-guided aspiration of tubal ectopic pregnancy followed by local $\mathrm{KCl}$ or intramuscular injection of MTX $\left(50 \mathrm{mg} / \mathrm{m}^{2}\right)$.

Main outcome measures: Successful conservative treatment of tubal ectopic pregnancies with preservation of fallopian tubes.

Results: Four (80\%) out of five women were successfully treated, without the need for operative intervention. One patient required salpingectomy for ruptured ectopic pregnancy during the course of treatment.

Conclusion: Transvaginal ultrasound-guided aspiration of ectopic gestational sac along with either local $\mathrm{KCl}$ or systemic methotrexate administration can be safely used to treat unruptured tubal ectopic pregnancies in selected patient population.

Keywords: Ectopic pregnancy, Transvaginal aspiration, Methotrexate, Ultrasound guided, Potassium chloride.

How to cite this article: Mishra VV, Choudhary S, Sharma U, Agarwal R. Transvaginal Aspiration of Ectopic Gestational Sac: A Novel Treatment Option in Tubal Ectopic Pregnancies. J South Asian Feder Obst Gynae 2015;7(1):1-4.

Source of support: Nil

Conflict of interest: None

\footnotetext{
${ }^{1}$ Professor and Head, ${ }^{2}$ Assistant Professor, ${ }^{3,4}$ Fellow

${ }^{1}$ Department of Obstetrics and Gynecology, Institute of Kidney Diseases and Research Centre, Ahmedabad, Gujarat, India

${ }^{2-4}$ Department of Obstetrics and Gynecology, Institute of Kidney Diseases and Research Centre, Institute of Transplantation Sciences, Ahmedabad, Gujarat, India

Corresponding Author: Vineet V Mishra, Professor and Head, Department of Obstetrics and Gynecology, Institute of Kidney Diseases and Research Centre, Ahmedabad, Gujarat India, Phone: 07922687038, e-mail: vineet.mishra.ikdrc@ gmail.com
}

\section{INTRODUCTION}

Ectopic pregnancy remains an important cause of maternal morbidity and mortality. The incidence is approximately 1.5 to $2 \%$ of all pregnancies. The risk for ectopic pregnancy is increased approximately 2 -fold for infertile women. Assisted reproduction also increases the risk of ectopic pregnancy by 2 -fold. The first pregnancy achieved with IVF was ectopic. ${ }^{1}$ The fallopian tube is the most common site of ectopic implantation, accounting for more than $98 \%$ of all ectopic pregnancies. Other rare sites include: ovarian, cervical and abdominal sites. With the use of high resolution transvaginal ultrasound, it is now possible to diagnose most ectopic pregnancies early. Management of tubal ectopic pregnancies with transvaginal sonography (TVS) guided aspiration and/or local injection may reduce the need for definitive surgical intervention and, therefore, allow for the preservation of uterus and fallopian tube integrity and future fertility. This ultrasound-guided method has been used to successfully treat ectopic pregnancy located in the fallopian tubes, interstitium, cervix, and abdomen, as well as for cesarean section scar pregnancies. Ultrasound may also be used to guide the laparoscopic treatment of ectopic pregnancy. ${ }^{2,3}$ Cepni $L$ et al have described management of tubal ectopic pregnancies by aspiration of the embryo followed by single dose MTX administration. ${ }^{4}$ Systemic MTX treatment has been shown to be particularly useful in cases of early, unruptured, tubal ectopic pregnancies, with a reported success rate of about $90 \% .{ }^{5}$ However, in cases of live tubal ectopic pregnancies, a failure rate of $30 \%$ has been reported using systemic MTX alone. ${ }^{6}$ TVS guided aspiration is advantageous as it avoids excessive blood loss, morbidity and limitation of reproductive capacity associated with surgical management. However, a timely diagnosis and management with proper followup is essential for the success of the treatment and to prevent the risk of rupture with its potentially fatal consequences.

The aim of this report was to describe five cases of tubal ectopic pregnancies which were managed with TVSguided aspiration along with either local $\mathrm{KCl}$ injection or intramuscular injection of MTX. 


\section{MATERIALS AND METHODS}

From October 2013 to 2014, five women were diagnosed with tubal ectopic pregnancies at Obstetrics and Gynecology Unit of Institute of Kidney Disease and Research Centre, Institute of Transplantation Sciences (IKDRC-ITS), Ahmedabad. Transvaginal ultrasound with Volusen E8 USG machine was used to diagnose ectopic pregnancies in women with positive urine pregnancy test or serum $\beta$-hCG titers positive for pregnancy. Tubal ectopic pregnancy was diagnosed when there was an empty uterine cavity with the presence of a tubal gestational sac with or without an embryo. After the sonographic diagnosis, the patients were thoroughly counseled regarding the treatment options available and their risks-benefits. TVS-guided aspiration of ectopic sac was performed using a 17 gauge oocyte aspiration needle in hemodynamically stable patients after obtaining informed consent. In two cases, $\mathrm{KCl}(0.5-1 \mathrm{ml}, 2 \mathrm{mEq} /$ $\mathrm{ml}$ solution) was injected into the sac, causing immediate cessation of cardiac activity. After the procedure, puncture site was observed sonographically for up to 10 minutes to detect hemorrhage. Patients were kept under observation for 48 hours. Intramuscular MTX (50 $\mathrm{mg} / \mathrm{m}^{2}$ body surface area) was administered in all cases with live ectopic pregnancies after confirming normal liver and renal functions. Patients were followed with TVS and weekly quantitative $\beta$-hCG titers until levels were undetectable.

\section{CASE REPORTS}

\section{Case 1}

A 25-year-old female with regular menstrual cycles, married for 4 years reported to this hospital with primary infertility. She underwent ovulation induction with clomiphene citrate $50 \mathrm{mg}$ once daily for 5 days from day 2 of cycle followed by intrauterine insemination (IUI). She conceived in second cycle of IUI and reported with a positive urine pregnancy test. TVS showed endometrial thickness of $14 \mathrm{~mm}$ with no evidence of gestational sac in endometrial cavity or adnexae. A repeat ultrasonography (USG) after 1 week revealed left tubal live ectopic pregnancy of 7 weeks.

Her initial serum $\beta$-hCG at the time of diagnosis was $29502.04 \mathrm{mIU} / \mathrm{ml}$. Systemic MTX (50 mg/m²) single dose was given on day 1 . On day 2, transvaginal ultrasound guided local administration of $\mathrm{KCl}(2 \mathrm{mEq} / \mathrm{ml})$ followed by aspiration of the sac was done. On day fifth, her $\beta$-hCG rose up to $36000 \mathrm{mIU} / \mathrm{ml}$ but after this initial rise, it started showing a reducing trend. After 2 weeks, her serum $\beta$-hCG was $15103 \mathrm{mIU} / \mathrm{ml}$ and it became undetectable 6 weeks after aspiration.

\section{Case 2}

A 24-year-old female married for 3 years with history of IUI in previous cycle presented with missed periods (1 month and 12 days), pain lower abdomen and spotting for 2 days. She had a history of diagnostic laparoscopy done for primary infertility 1 year earlier which showed normal uterus and ovaries with left tube patent and right tube blocked. Her urine pregnancy test was positive. Transvaginal USG revealed an empty uterine cavity with 6 week gestational sac with small fetal pole without cardiac activity in left adnexae. B/L ovaries were normal and there was no fluid in pouch of douglas. Her serum $\beta$-hCG was $2332.5 \mathrm{mIU} / \mathrm{ml}$. TVS-guided aspiration of ectopic gestational sac was done. Contents obtained were sent for histopathological examination. Simultaneous D and $C$ was done, and endometrial tissue was sent for HPE. Patient was kept under observation for 48 hours. After 4 days, her serum $\beta$-hCG was $3453 \mathrm{mIU} / \mathrm{ml}$. Histopathology report revealed products of conception in the aspirated material and decidual reaction in endometrium.

After 7 days, her $\beta$-hCG further rose to $9561 \mathrm{mIU} / \mathrm{ml}$. TVS showed left adnexal mass $(8 \times 8 \mathrm{~mm})$ and endometrial thickness of $13 \mathrm{~mm}$. Repeat transvaginal ectopic sac aspiration was done followed by intramuscular injection of methotrexate $\left(50 \mathrm{mg} / \mathrm{m}^{2}\right)$.

After 3 days, patient presented with acute abdominal pain with pallor and fainting attack. USG showed ruptured left tubal ectopic pregnancy with hemoperitoneum. Laparoscopic salpingectomy was done. Postoperative convalescence was smooth, and patient was discharged after 3 days.

\section{Case 3}

A 32-year-old female with secondary infertility and history of recurrent abortions underwent IVF followed by frozen embryo transfer in which three embryos were transferred in her uterine cavity. After 14 days of embryo transfer, her serum $\beta$-hCG was $260 \mathrm{mIU} / \mathrm{ml}$. Progesterone support was continued. After 4 days, patient presented with pain in lower abdomen and slight vaginal bleeding for 1 day. TVS showed empty uterine cavity with $7.5 \mathrm{~mm}$ endometrial thickness and no gestational sac could be seen inside or outside the uterine cavity. On that day, her serum $\beta$-hCG was $355 \mathrm{mIU} / \mathrm{ml}$. TVS after 1 week revealed an empty uterine cavity with endometrial thickness of $8.0 \mathrm{~mm}$ with an ectopic gestational sac of 6 weeks with cardiac activity in right fallopian tube. Serum $\beta$-hCG was $3104 \mathrm{mIU} / \mathrm{ml}$. After obtaining informed consent, TVS guided aspiration was performed followed by systemic $\operatorname{MTX}\left(50 \mathrm{mg} / \mathrm{m}^{2}\right)$ and patient was kept under observation for 48 hours. After 48 hours of procedure, serum $\beta$-hCG 
was $3768 \mathrm{mIU} / \mathrm{ml}$. On follow-up visit after 10 days of discharge, serum $\beta$-hCG levels came down to $1527 \mathrm{mIU} /$ $\mathrm{ml}$ and transvaginal scan was normal with no ectopic sac and a normal uterine cavity with endometrial thickness of $6.9 \mathrm{~mm}$. Patient resumed her normal menses 7 weeks after aspiration of ectopic pregnancy and, at that time, her serum $\beta$-hCG levels became undetectable.

\section{Case 4}

A 24-year-old female with secondary infertility (history of previous one abortion), underwent IVF with fresh embryo transfer. After 14 days of embryo transfer, her serum $\beta$-hCG was $131 \mathrm{mIU} / \mathrm{ml}$. After 2 weeks, on followup, TVS revealed a live ectopic pregnancy located in right fallopian tube with an empty uterine cavity. Serum $\beta$-hCG was $3008 \mathrm{mIU} / \mathrm{ml}$. Transvaginal aspiration of ectopic pregnancy was done and systemic MTX $\left(50 \mathrm{mg} / \mathrm{m}^{2}\right)$ was given intramuscularly. After 4 days of procedure, her serum $\beta$-hCG was $3500 \mathrm{mIU} / \mathrm{ml}$ but after 1 week, it came down to $2100 \mathrm{mIU} / \mathrm{ml}$. Serial $\beta$-hCG titers were performed until it became undetectable. Patient resumed normal menses 5 weeks after the procedure with disappearance of the ectopic mass on TVS.

\section{Case 5}

A 31-year-old female with history of primary infertility and absent left adnexae underwent in vitro fertilization (IVF) with embryo transfer. After 14 days of embryo transfer, her serum $\beta$-hCG was $4390 \mathrm{mIU} / \mathrm{ml}$ which came down to $2798 \mathrm{mIU} / \mathrm{ml}$ after 4 days of initial report. Two weeks later, right sided live ectopic pregnancy of 6 weeks was detected on USG. Her serum $\beta$-hCG on the same day was 20,200 mIU/ml. Transvaginal USG-guided ectopic aspiration was done following injection of $\mathrm{KCl}$ into the sac. She was also given intramuscular injection of four doses of methotrexate every alternate day alternating with folinic acid. Products sent for histopathological examination showed chorionic villi. After 4 days of procedure, her serum $\beta$-hCG rose to $22,526 \mathrm{mIU} / \mathrm{ml}$ and USG showed hemorrhagic mass at the site of ectopic pregnancy. One week later, her serum $\beta$-hCG came down to $12,488 \mathrm{mIU} / \mathrm{ml}$ and 10 days later to $1733 \mathrm{mIU} / \mathrm{ml}$ while TVS showed a right adnexal mass of $2.6 \times 2.6 \mathrm{~cm}$. She got her menses 5 weeks after aspiration when the serum $\beta$-hCG titer was negative for pregnancy and the ectopic mass resolved completely within 8 weeks.

\section{RESULTS}

During 1 year, five women were diagnosed with unruptured tubal ectopic pregnancies. Age of the patients ranged from 24 to 32 years with an average age of 27.2 years.
Mean gestational age at the time of procedure was 6.2 weeks. Mean serum $\beta$-hCG at the time of procedure was $11629.3 \mathrm{mIU} / \mathrm{ml}$. All (100\%) of the women had a history of infertility. Two ( $40 \%$ ) out of five women conceived after IUI and the other three (60\%) after IVF (Table 1). Four $(80 \%)$ of them had live ectopic pregnancies while in one $(20 \%)$, there was no cardiac activity. Transvaginal ectopic sac aspiration was done in all the cases. In two $(40 \%)$ of the cases, local injection of $\mathrm{KCl}$ was given at the time of aspiration. In three $(60 \%)$ patients with live ectopic pregnancy, single dose of systemic MTX $(50 \mathrm{mg} /$ $\mathrm{m}^{2}$ ) was administered while in one case, four doses of MTX were given alternating with folinic acid. In the woman with ectopic pregnancy without cardiac activity, serum $\beta$-hCG titers continued to rise after the procedure, so repeat aspiration of the ectopic pregnancy was done which was followed by systemic MTX administration. In four patients, there were no complications and required no further treatment. One patient who required double aspiration developed ruptured ectopic for which emergency surgery followed by salpingectomy was done as shown in Table 2.

\section{DISCUSSION}

In a selected patient population, most of the unruptured, live ectopic pregnancies can be successfully managed without surgical intervention using ultrasound-guided aspiration and injection with $\mathrm{KCl}$ or MTX. Andres MP et al have demonstrated the successful management of ectopic pregnancies with the use of ultrasound guided injection of fetotoxic substances like methotrexate into the intraamniotic and/or intrachorionic sac. ${ }^{7}$ Dadhwal et al reported successful management of live tubal ectopic pregnancy with local $\mathrm{KCl}$ and systemic MTX administration. ${ }^{8}$ Verma and Jacques reported three cases that were treated using ultrasound-guided intrasac $\mathrm{KCl}$ injection and systemic MTX. In all three cases, the resolution of ectopic pregnancy was achieved, and surgery was avoided. ${ }^{9}$ Doubilet et al reported their experience using sonographically guided treatment of ectopic pregnancies (cervical, tubal and cornual) with $\mathrm{KCl}$ injection. Their series had a total of 27 patients of which 25 (93\%) were successfully treated..$^{10}$

Table 1: Patient characteristics

\begin{tabular}{llll}
\hline $\begin{array}{l}\text { Case } \\
\text { no. }\end{array}$ & Age at presentation (years) & $\begin{array}{l}\text { Type of } \\
\text { infertility }\end{array}$ & $\begin{array}{l}\text { Conceived } \\
\text { after }\end{array}$ \\
\hline 1 & 25 & Primary & IUI \\
2 & 24 & Primary & IUI \\
3 & 32 & Secondary & IVF \\
4 & 24 & Secondary & IVF \\
5 & 31 & Primary & IVF \\
\hline
\end{tabular}


Table 2: Summary of characteristics of patients treated with TVS-guided aspiration of ectopic pregnancy

\begin{tabular}{|c|c|c|c|c|c|c|c|}
\hline $\begin{array}{l}\text { Serial } \\
\text { no. }\end{array}$ & $\begin{array}{l}\text { Location } \\
\text { of ectopic } \\
\text { sac }\end{array}$ & $\begin{array}{l}\text { Gestational age in } \\
\text { weeks }\end{array}$ & $\begin{array}{l}\text { Serum } \beta \text {-hCG } \\
\text { (m/U/ml) on day } \\
\text { of aspiration }\end{array}$ & $\begin{array}{l}\text { Local } \\
\text { injection }\end{array}$ & $\begin{array}{l}\text { Intramuscular } \\
\text { MTX }\left(50 \mathrm{mg} / \mathrm{m}^{2}\right)\end{array}$ & $\begin{array}{l}\text { Repeat } \\
\text { aspiration }\end{array}$ & $\begin{array}{l}\text { Complications } \\
\text { (if any) }\end{array}$ \\
\hline 1 & Left tube & $\begin{array}{l}7 \text { weeks, cardiac } \\
\text { activity present }\end{array}$ & 29502 & $\mathrm{KCl}$ & Yes & No & Nil \\
\hline 2 & Left tube & $\begin{array}{l}6 \text { weeks, no } \\
\text { cardiac activity }\end{array}$ & 2332.5 & No & $\begin{array}{l}\text { Yes (after repeat } \\
\text { aspiration) }\end{array}$ & Yes & $\begin{array}{l}\text { Developed ruptured ectopic } \\
\text { for which salpingectomy was } \\
\text { done }\end{array}$ \\
\hline 3 & Right tube & $\begin{array}{l}6 \text { weeks, cardiac } \\
\text { activity present }\end{array}$ & 3104 & No & Yes & No & Nil \\
\hline 4 & Right tube & $\begin{array}{l}6 \text { weeks, cardiac } \\
\text { activity present }\end{array}$ & 3008 & No & Yes & No & Nil \\
\hline 5 & Right tube & $\begin{array}{l}6 \text { weeks, cardiac } \\
\text { activity present }\end{array}$ & 20200 & $\mathrm{KCl}$ & Yes & No & Nil \\
\hline
\end{tabular}

Patients should be thoroughly counseled about the risks involved with this procedure and should be explained that it is difficult to predict which patient will have complications following the treatment. Infertility is a known risk factor associated with ectopic pregnancies. In this series, all (100\%) patients were infertile and were taking treatment for infertility. Three out of five women had conceived after IVF and other two after IUI.

Transvaginal aspiration of ectopic pregnancies requires experience in invasive ultrasound-guided procedures. Also, proper patient selection and followup is very essential as it takes many weeks for serum $\beta$-hCG to become undetectable (in our series about 6 weeks). After aspiration, there is an initial rise in the serum $\beta$-hCG titer. Similarly, in some cases, the size of the gestational sac may also increase after the procedure. So, we follow these patients for several weeks with serial TVS to see for decrease in size of ectopic mass and till the $\beta$-hCG titer is undetectable. In most cases, menstruation resumes when the $\beta$-hCG titer is negative for pregnancy or very close to negative. Four out of five women in this series had no complication but one developed ruptured ectopic pregnancy for which emergency surgery was done.

Conservative management of ectopic pregnancy should be done at a center where patient can be monitored closely and any complication can be managed immediately.

\section{CONCLUSION}

Unruptured tubal ectopic pregnancies can be managed conservatively in carefully selected patient population. However, these patients need extensive counseling regarding the risk of treatment failure and/or complications and the need for regular follow-up. More studies are required to determine the success and feasibility of this procedure.

\section{REFERENCES}

1. Steptoe PC, Edwards RG. Reimplantation of a human embryo with subsequent tubal pregnancy. Lancet 1976;1(7965): 880-882.

2. Chen $\mathrm{CH}$, Wang PH, Liu WM. Successful treatment of cesarean scar pregnancy using laparoscopically assisted local injection of etoposide with transvaginal ultrasound guidance. Fertil Steril 2009;92(5):1747.e9-1747.e11.

3. Poujade O, Ducarme G, Luton D. Cornual heterotopic pregnancy: a case report. J Med Case Reports 2009;3:7233.

4. Cepni I, Guralp O, Ocal P, Salahov R, Gurleyen H, Idil M. An alternative treatment option in tubal ectopic pregnancies with fetal heartbeat: aspiration of the embryo followed by a single-dose methotrexate administration. Fertil Steril 2011; 96(1):79-83.

5. Lipscomb GH, Bran D, McCord ML. Analysis of three hundred fifteen ectopic pregnancies treated with single-dose methotrexate. Amj Obstet Gynecol 1998;178(6):1354-1358.

6. Lipscomb GH, McCord ML, Stovall TG, Huff G, Portera SG, Ling FW. Predictors of success of methotrexate treatment in women with tubal ectopic pregnancies. N Engl J Med 1999; 341(26):1974-1978.

7. Andres MP, Campillos JM, Lapresta M, Lahoz I, Crespo R, Tobajas J. Management of ectopic pregnancies with poor prognosis through ultrasound guided intrasacular injection of methotrexate, series of 14 cases. Arch Gynecol Obstet 2012; 285(2):529-533.

8. Dadhwal V, Deka D, Ghosh B. Successful management of live ectopic pregnancy with high beta-hCG titres by ultrasoundguided potassium chloride injection and systemic methotrexate. Arch Gynecol Obstet 2009;280(5):799-801.

9. Verma U, Jacques E. Conservative management of live tubal pregnancies by ultrasound guided potassium chloride injection and systemic methotrexate treatment. J Clin Ultrasound 2005;33(9):460-463.

10. Doubilet PM, Benson CB, Frates MC, Ginsburg E. Sonographically guided minimally invasive treatment of unusual ectopic pregnancies. J Ultrasound Med 2004;23(3):359-437. 